\title{
ANALISIS HUBUNGAN ANTARA FINANCIAL LITERACY DAN FINANCIAL DISTRESS PADA DEWASA MUDA DI KOTA BANDUNG
}

\author{
Asyiffa Fitria Awallia \\ School of Economics and Business, Telkom University \\ awalliaasyiffa@yahoo.com \\ Andrieta Shintia Dewi \\ School of Economics and Business, Telkom University \\ andrieta.shintia@gmail.com
}

\begin{abstract}
ABSTRAK
Penelitian ini bertujuan untuk mengetahui hubungan antara financial literacy dan financial distress pada Dewasa Muda di Kota Bandung. Metode penelitian menggunakan pendekatan metode kuantitatif. Pengumpulan data dilakukan dengan penyebaran kuesioner kepada Dewasa Muda di Kota Bandung. Sampel terpilih sebanyak 400 orang melalui convenience sampling. Alat ukur yang digunakan pada penelitian ini adalah skala likert untuk variabel financial literacy dan The InCharge Financial Distress/Financial Well-being (IFDFW) untuk variabel financial distress. Item yang digunakan pada variabel financial literacy sebanyak 21 item pernyataan dan variabel financial distress sebanyak 8 pernyataan. Teknik analisis dalam penelitian ini menggunakan analisis deskriptif dan analisis korelasi parametik pearson product moment. Pengujian data menggunakan uji normalitas Kolmograv-Smirnov. Berdasarkan hasil yang diperoleh tingkat financial literacy pada Dewasa Muda di Kota Bandung tinggi dan tingkat financial distress pada dewada muda di Kota Bandung sedang. Selain itu, penelitian ini menunjukan bahwa terdapat hubungan positif dan kuat antara financial literacy dan financial distress pada Dewasa Muda di Kota Bandung.
\end{abstract}

Kata Kunci: Financial literacy, Financial distress, Dewasa Muda, Kota Bandung

\section{Pendahuluan}

Pengetahuan seseorang untuk mengelola keuangan (financial literacy) sangatlah dibutuhkan, dengan adanya financial literacy diharapkan dapat membantu meningkatkan kemampuan seseorang untuk menghasilkan inovasi dan akhirnya dapat meningkatnya Gross Domestic Product suatu negara serta dapat membantu kalangan muda untuk membuat keputusan yang tepat mengenai situasi keuangan mereka (Idris et al., 2013).

Tingkat menabung atau perilaku menabung merupakan salah satu dimensi financial literacy (Chen \& Volpe, 1998). Menurut Data Kajian Stabilitas Keuangan Bank Indonesia No. 27 September 2016, masyarakat tidak bisa menabung pada semester I 2016 mengalami peningkatkan menjadi 26,82\% dibandingkan semester II 2015 yaitu 18.51\%. Tingginya tingkat masyarakat tidak bisa menabung di Indonesia mengindikasikan bahwa tingkat financial literacy di Indonesia rendah.

Selain tingkat menabung, Chen \& Volpe (1998) menyatakan bahwa pinjaman atau perilaku kredit termasuk salah satu dimensi financial literacy. 


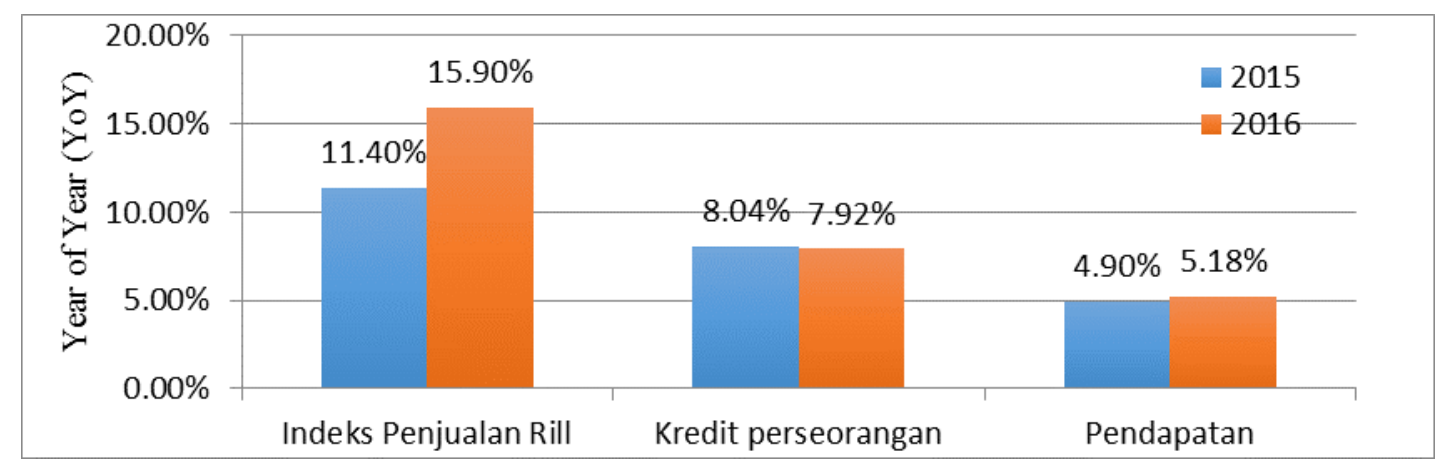

\section{Gambar 1. Grafik Pertumbuhan IPR, Kredit Perseorangan dan Pendapatan Indonesia September 2016}

Berdasarkan gambar 1 tersebut, yang bersumber dari Kajian Stabilitas Keuangan Bank Indonesia No. 27 September 2016, menunjukan bahwa peningkatan Indeks Penjualan Rill diiringi pertumbuhan kredit perseorangan yang nilainya terus meningkat namun pertumbuhannya cenderung menurun serta pertumbuhan pendapatan yang lebih kecil dibanding kredit perseorangan, mengindikasikan adanya kemudahan kredit yang dapat menarik masyarakat untuk meminjam uang walaupun bukan keharusan mereka untuk melakukannya (Idris et al., 2013). Ini mengindikasikan budaya hedonisme dan sifat konsumtif pada masyarakat Indonesia. Pola hidup yang konsumtif ini dapat menyebabkan terjadinya kemungkinan risiko kredit macet yang akan terjadi ketika mengambil kredit tetapi hanya sekedar ingin memenuhi kebutuhan gaya hidup semata (Tsalitsa \& Rachmansyah, 2016). Ketidakmampuan masyarakat Indonesia untuk menentukan pengambilan sistem kredit yang tepat mengindikasikan bahwa tingkat financial literacy masyarakat Indonesia rendah.

Berdasarkan data mengenai perilaku menabung di Indonesia yang masih rendah serta adanya ketidakmampuan masyarakat Indonesia untuk menentukan sistem kredit dengan tepat dapat diartikan bahwa tingkat financial literacy di Indonesia masih rendah. Kurangnya pengetahuan dan keterampilan untuk mengelola keuangan (financial literacy) akan memperburuk tingkat stress. Tingkat stress yang semakin meningkat akan mengakibatkan adanya financial distress (Idris et al., 2013).

Financial distress adalah tahap penurunan kondisi keuangan yang terjadi sebelum terjadinya kebangkrutan atau likuidasi (Platt \& Platt, 2002). Financial distress timbul dari kurangnya tanggung jawab pribadi seperti sikap negatif terhadap pembayaran tagihan dan keengganan membayar hutang (Stamp, 2009). 
Tabel 1. Pertumbuhan dan NPL Kredit Perseorangan

\begin{tabular}{lccc}
\multicolumn{1}{c}{ Jenis } & Juni 2015 & Desember 2015 & Juni 2016 \\
Penggunaan & & $3,75 \%$ & $4,21 \%$ \\
Modal Kerja & $3,93 \%$ & $4,53 \%$ & $5,01 \%$ \\
Investasi & $3,92 \%$ & $1,51 \%$ & $1,68 \%$ \\
Konsumsi & $1,69 \%$ & $2,47 \%$ & $2,76 \%$ \\
\hline TOTAL & $2,58 \%$ & & \\
\hline
\end{tabular}

Sumber: Kajian Stabilitas Keuangan Bank Indonesia No. 27 September 2016

Meningkatnya persentase NPL di Indonesia merupakan keadaan dimana masyarakat Indonesia sudah tidak sanggup membayar sebagian atau seluruh hutangnya, hal ini merupakan sikap negatif terhadap pembayaran tagihan ataupun terdapat keengganan membayar hutang. Berdasarkan hal tersebut, maka penulis tertarik untuk mengetahui dan menganalisis mengenai hubungan financial literacy dengan financial distress.

\section{Pustaka}

\section{Financial Literacy}

Financial literacy adalah kemampuan seseorang untuk mengelola keuangan pribadi, seperti investasi dalam jangka waktu panjang untuk pensiun maupun untuk pendidikan anak, mengelola dana untuk menabung dalam jangka waktu pendek dan meminjam untuk liburan, pembayaran rumah, cicilan mobil dan lainnya. Serta, mengelola biaya kesehatan dan asuransi yang dibutuhkan (Chen \& Volpe, 1998). Dalam Shockey (2002), financial literacy dapat dilihat dari skor tiga dimensi yang biasa disebut ABK, yaitu financial attitude, financial behavior dan financial knowledge.

Ketika seseorang memiliki tingkat financial literacy yang baik maka mereka mampu membuat keputusan keuangan yang lebih baik, percaya diri membuat keputusan investasi, mengubah strategi investasi dengan tepat serta memiliki situasi keuangan yang membaik (Garman et al., 1999). Sedangkan financial literacy yang buruk membuat seseorang memiliki opini yang salah dan membuat keputusan yang salah dalam pengetahuan dasar, saving and borrowing maupun dalam investasi (Chen \& Volpe, 1998).

\section{Financial Distress}

Financial distress adalah ketegangan fisik atau mental yang intens yang mencakup kekhawatiran mengenai keuangan yang dapat bertahan dalam waktu singkat atau bisa menjadi persisten (Prawitz et al., 2006). Financial distress dapat didefinisikan sebagai reaksi, seperti 
ketidaknyamanan mental atau fisik, untuk menekankan tentang keadaan keuangan umum seseorang (o’Neill et al., 2006).

Idris et al., (2013) menyatakan financial distress mengakibatkan seseorang berhenti membayar tagihan, menerima pemberitahuan hutang yang dibayar maupun menerima panggilan dari kreditor. Financial distress pun memberikan dampak negatif terhadap produktivitas di tempat kerja. Disisi lain, financial distress tidak selamanya dipandang negatif. Financial distress dapat menjadi sumber motivasi untuk meningkatkan produktivitas dan pendapatan.

\section{Hubungan Antara Financial Literacy dan Financial Distress}

Penelitian mengenai hubungan antara financial literacy dan financial distress sudah dilakukan oleh beberapa peneliti diberbagai negara dengan objek yang berbeda. Berdasarkan hasil dari penelitian sebelumnya diperoleh hasil yang berbeda-beda yang dapat dilihat pada Tabel 2.

Tabel 2. Perbedaan Hasil Penelitian Terdahulu

\begin{tabular}{lll}
\multicolumn{1}{c}{ Penulis dan Tahun } & \multicolumn{1}{c}{ Objek Penelitian } & \multicolumn{1}{c}{ Hasil } \\
\hline Idris et al., (2013) & Dewasa Muda di Malaysia & Terdapat hubungan \\
\hline Adam et al., (2017) & $\begin{array}{l}\text { Pensiunan di Cape Coast } \\
\text { Metropolis, Ghana }\end{array}$ & Terdapat hubungan \\
\hline Taft et al., (2013) & Profesor di Tow University, Iran & Terdapat hubungan \\
\hline Sabri \& Zakaria (2015) & Karyawan muda di Malayasia & Terdapat hubungan \\
\hline Vu \& Scott (2017) & Masyarakat $>18$ tahun di Colombia & Terdapat hubungan \\
\hline
\end{tabular}

Sumber: Hasil Olahan Penulis

Berdasarkan penelitian terdahulu yang membahas mengenai hubungan antara financial literacy dan financial distress, penulis dapat mengambil kesimpulan bahwa financial literacy memiliki hubungan dengan financial distress. Hal ini dapat diperkuat dengan adanya pembuktian oleh peneliti terdahulu yang telah dilakukan dengan objek penelitian yang berbeda-beda. Adapun hipotesis yang diajukan dalam penelitian ini sebagai berikut:

\section{$\mathbf{H}=$ financial distress memiliki hubungan dengan financial literacy}

\section{Metode}

Penelitian dilakukan pada Dewasa Muda di Kota Bandung. Populasi dalam penelitian ini berjumlah 489.575 orang dengan jumlah sampel sebanyak 400 orang yang diharapkan mampu mewakili populasi yang ada. Detail demografis responden disajikan pada Tabel 3 Waktu penelitian dimulai dari bulan September hingga Desember 2018. 
Teknik analisis yang digunakan dalam penelitian ini adalah analisis deskriptif dan analisis korelasi parametik pearson product moment. Penelitian deskriptif dilakukan untuk mendeskripsikan tingkat financial literacy dan financial distress pada Dewasa Muda di Kota Bandung, sementara analisis korelasi parametik pearson product moment adalah analisis untuk mengetahui ada dan tidaknya hubungan dua variabel, yaitu variabel bebas dan variabel tergantung yang berskala interval (Sarwono,2006). Selain itu, penelitian ini menggunakan uji normalitas untuk mengetahui apakah data yang diambil baik dan layak dengan menggunakan uji kolmogrov-smirnov.

Dalam penelitian ini pernyataan kuesioner mengenai financial literacy menggunakan 21 item dengan skala yang digunakan yaitu skala likert, skala ini terdiri dari sangat tidak setuju (1), tidak setuju (2), cukup setuju (3), setuju (4) dan sangat setuju (5). Sedangkan pernyataan kuesioner mengenai financial distress menggunakan 8 item dengan skala IFDFW, skala ini terdiri dari financial distress yang luar biasa (1), financial distress yang sangat amat tinggi (2), financial distress yang sangat tinggi (3), financial distress yang tinggi (4), financial distress yang sesuai rata-rata (5), financial distress yang sedang, financial distress yang rendah (7), financial distress yang sangat rendah (8), financial distress yang sangat amat rendah (9), dan tidak terdapat financial distress (10).

Tabel 3. Aspek Demografi

\begin{tabular}{lccc}
\hline $\begin{array}{c}\text { Faktor } \\
\text { Demografi }\end{array}$ & Klasifikasi & $\begin{array}{c}\text { Jumlah } \\
\text { Responden }\end{array}$ & \% \\
\hline Jenis & Perempuan & 245 & $61,3 \%$ \\
Kelamin & Laki-laki & 155 & $38,7 \%$ \\
\hline \multirow{3}{*}{ Pendapatan } & Rp 1.000.000 - Rp 2.000.000 & 55 & $13,8 \%$ \\
per Bulan & Rp 2.000.001 - Rp 3.000.000 & 160 & $40 \%$ \\
& $>$ Rp 3.000.000 & 68 & $29,3 \%$ \\
& SMA & 285 & $71,25 \%$ \\
Pendidikan & S1 & 97 & $24,25 \%$ \\
Terakhir & S2 & 18 & $4,5 \%$ \\
& Sendiri & 267 & $66,8 \%$ \\
Tempat & Bersama orangtua & 133 & $33,2 \%$ \\
Tinggal & & & \\
\hline
\end{tabular}

Sumber: Hasil Penelitian, diolah (2018)

Berdasarkan hasil penelitian sebesar 61,3\% merupakan kelompok perempuan dan sisanya sebesar 38,7\% merupakan kelompok laki-laki. Hal ini menunjukan bahwa jumlah responden mayoritas perempuan dan menunjukan bahwa Dewasa Muda di Kota Bandung didominasi oleh perempuan dibandingkan laki-laki. Kemudian berdasarkan pendapatan per 
bulan kelompok responden paling banyak merupakan kelompok dengan pendapatan per bulan sebesar Rp 1.000.000 hingga Rp 2.000.000 dengan jumlah responden sebanyak 160 responden atau sebesar $40 \%$. Selanjutnya diketahui bahwa paling banyak responden termasuk dalam kelompok dengan pendidikan terakhir SMA dengan jumlah 285 responden, hal ini menunjukan bahwa Dewasa Muda di Kota Bandung didominasi oleh lulusan SMA atau sedang menempuh pendidikan S1 karena masa Dewasa Muda merupakan masa dimana seseorang mempunyai tugas untuk melanjutkan pendidikan serta diketahui lebih banyak responden yang tinggal sendiri dibandingkan bersama orangtua, dengan jumlah 267 responden atau sebesar $66,8 \%$.

\section{Hasil dan Pembahasan}

Penelitian ini menggunakan uji asumsi klasik yaitu uji normalitas, analisis deskriptif dan analisis korelasi parametik pearson product moment. Uji normalitas dilakukan untuk mengetahui apakah data yang diambil baik dan layak dengan menggunakan uji kolmogrovsmirnov.

Hasil pengolahan data pada uji normalitas disajikan pada tabel 4 yang menunjukan nilai Asymp. Sig (2-tailed) sebesar 0,069 yang artinya data dalam penelitian ini data berdistribusi normal.

Tabel 4. Uji Normalitas

\begin{tabular}{cc}
\hline \multicolumn{2}{c}{ One-Sample Kolmogorv-Smirnov Test } \\
\hline Kolmogorov-Smirnov Z & 0,043 \\
Asymp. Sig (2-tailed) & 0,069 \\
\hline
\end{tabular}

a. Test distribution is Normal

b. Calculated from data

Hasil analisis deskriptif untuk varibel financial literacy Berdasarkan tanggapan responden diketahui bahwa persentase variabel financial literacy sebesar 73\%. Penggambaran terhadap hasil tanggapan pada variabel financial literacy dari jawaban kuesioner yang diisi responden dapat dilihat pada Gambar 2. dalam bentuk garis kontinum. 


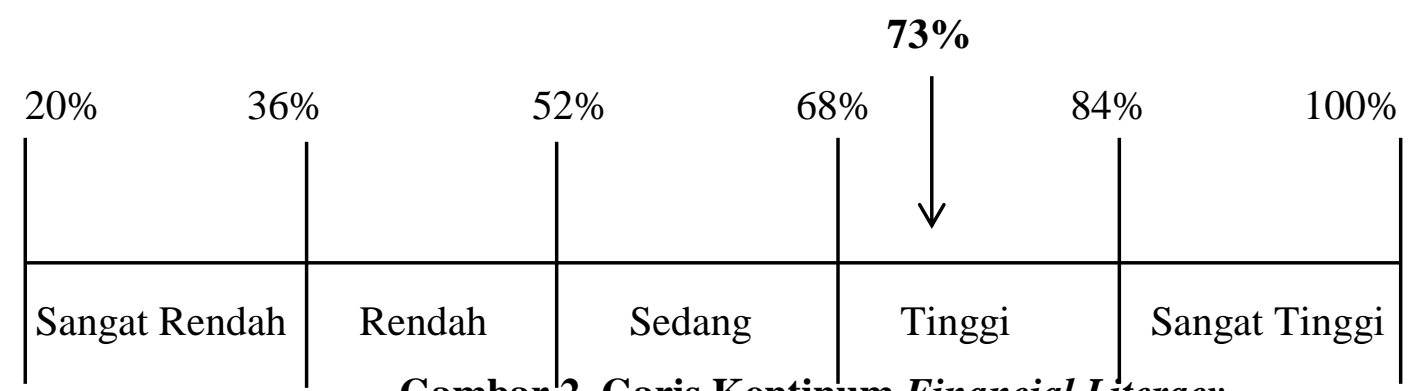

Gambar 2. Garis Kontinum Financial Literacy

Gambar 2 garis kontinum financial literacy menunjukan bahwa nilai persentase variabel financial literacy berada dalam klasfikasi tinggi dengan nilai sebesar $73 \%$.

Hasil analisis deskriptif untuk variabel financial distress berdasarkan tanggapan responden disajikan pada tabel 5.

Tabel 5. Tanggapan Responden Untuk Variabel Financial Distress

\begin{tabular}{ccc}
\hline Item & Jumlah Poin & Skor \\
\hline FD1 & 2466 & 6.2 \\
FD2 & 2457 & 6.1 \\
FD3 & 2434 & 6.1 \\
FD4 & 2352 & 5.9 \\
FD5 & 1893 & 4.7 \\
FD6 & 2556 & 6.4 \\
FD7 & 2987 & 7.5 \\
FD8 & 2600 & 6.5 \\
\hline \multicolumn{3}{c}{ Mean } \\
\hline
\end{tabular}

Berdasarkan tanggapan responden terhadap financial distress pada tabel 5. dapat diketahui bahwa tingkat financial distress pada Dewasa Muda di Kota Bandung memiliki nilai mean sebesar 6,2. Jika nilai mean berada pada rentang 4,1-6,9 maka tingkat financial distress masuk kedalam kategori sedang.

Selanjutnya analisis korelasi parametik pearson product moment untuk mengetahui ada tidaknya hubungan antara financial literacy dan financial distress disajikan pada tabel 6.

Tabel 6. Analisis Korelasi Parametik Pearson Product Moment

\begin{tabular}{cccc}
\hline \multicolumn{4}{c}{ Correlations } \\
\hline & FL & FD \\
\hline FL & Pearson Correlation & 1 &, $597^{* *}$ \\
& Sig. (2-tailed) & &, 000 \\
& N & 400 & 400 \\
\hline FD & Pearson Correlation &, $597^{* *}$ & 1 \\
& Sig. (2-tailed) &, 000 & \\
& N & 400 & 400 \\
\hline & $* *$. Correlation is significant at the 0,01 level (2-tailed
\end{tabular}


Tabel 6 menunjukan angka pearson correlation antara financial literacy dan financial distress sebesar 0,597 dengan nilai korelasi positif yang artinya terdapat hubungan antara financial literacy dan financial distress pada Dewasa Muda di Kota Bandung.

Tingkat financial literacy pada Dewasa Muda di Kota Bandung diidentifikasi melalui hasil tanggapan responden terhadap kuesioner dengan melakukan analisis deskriptif. Berdasarkan hasil tanggapan responden terhadap financial literacy didapatkan bahwa nilai rata-rata Dewasa Muda di Kota Bandung sebesar 73\%, nilai tersebut berarti tingkat financial literacy Dewasa Muda di Kota Bandung tinggi dengan kata lain Dewasa Muda di Kota Bandung mampu membuat penilaian dan mengambil keputusan yang efektif mengenai penggunaan dan pengelolaan uang mereka. Keadaan ini berbanding terbalik dengan tingkat financial literacy di Indonesia yang telah diidentifikasi oleh OJK. Pada tahun 2016, OJK mengatakan bahwa tingkat financial literacy di Indonesia sebesar 29,7\% dan termasuk kedalam kategori yang sangat rendah. Hal ini dapat terjadi karena terdapat perbedaan waktu pada saat melakukan identifikasi tingkat financial literacy, penulis tidak dapat membandingkan dengan data terkini karena OJK mempublikasikan Strategi Nasional Literasi Keuangan Indonesia (SNKLI) dua tahun sekali dan akan mempublikasikan lagi pada tahun 2019. Selain itu, besarnya perbedaan tingkat financial literacy di Indonesia dan di Bandung dapat terjadi karena responden yang penulis amati hanyalah Dewasa Muda dan tinggal di Kota Bandung saja, bukan merupakan gabungan dari seluruh wilayah di Indonesia.

Selain tingkat financial literacy, tingkat financial distress pun diidentifikasi melalui hasil tanggapan responden terhadap kuesioner dengan melakukan analisis deskriptif. Kuesioner menggunakan skala The InCharge Financial distress/financial well-being (IFDFW). Berdasarkan hasil tanggapan responden terhadap financial distress didapatkan bahwa nilai rata-rata Dewasa Muda di Kota Bandung sebesar 6,2. Jika nilai mean berada pada rentang 4,1 - 6,9 maka tingkat financial distress masuk kedalam kategori sedang. Dengan kata lain Dewasa Muda di Kota Bandung merasakan financial distress namun tidak luar biasa tertekan, mereka bisa saja berada dalam penurunan kondisi keuangan namun tidak secara signifikan, ataupun merasakan tidak nyaman dan tertekan tentang keadaan keuangan. Hal ini dapat terjadi karena kurangnya tanggung jawab pribadi untuk mengatur uang, mengeluarkan uang yang berlebihan maupun boros.

Hasil analisis membuktikan penelitian Idris et al., (2013) yang menyatakan bahwa terdapat hubungan positif antara financial literacy dan financial distress. Namun pada 
penelitian Idris et al., (2013) menyatakan bahwa hubungan tersebut lemah, berbeda dengan penelitian yang dilakukan oleh penulis pada Dewasa Muda di Kota Bandung. Angka korelasi antara financial literacy dan financial distress di Kota Bandung adalah 0,597 yang artinya terdapat hubungan yang kuat antara financial literacy dan financial distress di Kota Bandung. Keadaan tersebut menunjukan bahwa $\mathrm{H}_{1}$ diterima, karena terdapat hubungan antara financial literacy dan financial distress.

Selain mempunyai hubungan yang kuat, hubungan antara financial literacy dan financial distress pada Dewasa Muda di Kota Bandung bersifat positif, dengan kata lain jika variabel financial literacy meningkat maka variabel financial distress meningkat pula. Hal ini mengindikasikan Dewasa Muda di Kota Bandung memanfaatkan financial literacy yang dimilikinya secara berlebihan. Dewasa Muda cenderung mengeluarkan dana untuk investasi, menabung, dan memilih asuransi saat ini untuk menikmati keuntungan dimasa depan meskipun resikonya mereka mengalami financial distress.

\section{Simpulan}

Tingkat financial literacy pada dewasa muda di Kota Bandung tinggi dengan nilai rata-rata $73 \%$ serta tingkat financial distress pada dewasa muda di Kota Bandung sedang dengan nilai rata-rata 6,2, artinya dewasa muda di Kota Bandung mampu membuat penilaian dan mengambil keputusan yang efektif mengenai penggunaan dan pengelolaan uang mereka dan merasakan financial distress namun tidak luar biasa tertekan, mereka bisa saja berada dalam penurunan kondisi keuangan namun tidak secara signifikan, ataupun merasakan tidak nyaman dan tertekan tentang keadaan keuangan

Berdasarkan hasil analisis dapat disimpulkan bahwa $\mathrm{H}_{1}$ diterima, karena terdapat hubungan antara financial literacy dan financial distress dengan angka korelasi antara financial literacy dan financial distress pada dewasa muda di Kota Bandung sebesar 0,597 yang artinya terdapat hubungan yang kuat antara financial literacy dan financial distress pada dewasa muda di Kota Bandung. Selain mempunyai hubungan yang kuat, hubungan antara financial literacy dan financial distress pada dewasa muda di Kota Bandung bersifat positif, dengan kata lain jika variabel financial literacy meningkat maka variabel financial distress meningkat pula. 


\section{Daftar Pustaka}

Adam, A.M., Frimpong, S., Boadu, M.O. (2017). Financial literacy and financial planning: Implications for financial well-being of retirees. Business and Economic Horizons, 13(2). 224-236.

Chen, H., \& Volpe, R.P. (1998). An analysis of personal financial literacy among college students. Financial Services Review, 7 (2). 107 - 128.

Garman, T.E., Kim, J., Kratzer, C.Y., Brunson, B.H., Joo, S.H. (1999). Workplace financial education improves personal financial wellness, Financial Counselling and Planning, 10 (1). 79 - 88.

Idris, F.H., Krishnan, K.S.D., Azmi, N. (2013). Relationship between financial literacy and financial distress among youths in Malaysia: An empirical study, Malaysian Journal of Society and Space, 9(4). 106 - 117.

Kajian Stabilitas Keuangan Bank Indonesia No. 27. (2016). Mitigasi Risiko Sistemik dan Penguatan Intermedasi Dalam Upaya Menjaga Stabilitas Sistem Keuangan. Jakarta, Indonesia: Bank Indonesia.

O’Neill, B., Sorhaindo, B., Prawitz, A., Kim, J., Garman, T.E. (2006). Financial Distress: Definition, Effects and Measurement. Consumer Interest Annual, 52. 489 - 496.

Platt, H.D., \& Platt, B.M. (2002). Predicting Corporate Financial Distress: Reflection on Choice- Based Sample Bias. Journal of Economics and Finance, 26(2), 184-185.

Prawitz, A.D., Garman, E.T., Sorhaindo, B., O’Neill, B., Kim, J., \& Drentea, P. (2006). The InCharge Financial Distress/Financial Well-Being Scale: Development, inistration, and score interpretation. Financial Counseling and Planning, 17(1), 34-50.

Sabri, M.F., \& Juen, T.T. (2014). The Effects of Financial Literacy, Financial Management and Saving Motives on Financial Well-being among Working Women. Journal of Wealth Management \& Financial Planning. 1. 20-32.

Sarwono, J. (2006). Analisis Data Penelitian Menggunakan SPSS. Yogyakarta: Andi Offset.

Shockey, S.S. (2002). Low-wealth Adults financial literacy. Money management behavior and associates factors, including critical thinking (Unpublished Doctoral Dissertation). The Ohio StateUniversity, AAT 3039524.

Stamp, S. (2009). An exploratory analysis of financial difficulties among those living below the poverty line in Ireland. Combat Poverty Agency Working Paper Series, 9(2). 1-92.

Taft, M.K., Hosein, Z.Z., Mehrizi, S.M.T., Roshan, A. (2013). The Relation between Financial Literacy, Financial Wellebeing and Financial Concerns. International Journal of Business and Management. 8(11). 63 - 75.

Tsalitsa, A. \& Rachmansyah, Y. (2016). Analisis Pengaruh Literasi Keuangan Dan Faktor Demografi terhadap Pengambilan Kredit Pada PT. Columbia Cabang Kudus. Media Ekonomi dan Manajemen, 31(1). 2-13.

Vu, N.N., \& Scott, J. (2017). Financial Capability: Literacy, Behavior, and Distress. SSRN. 137. 